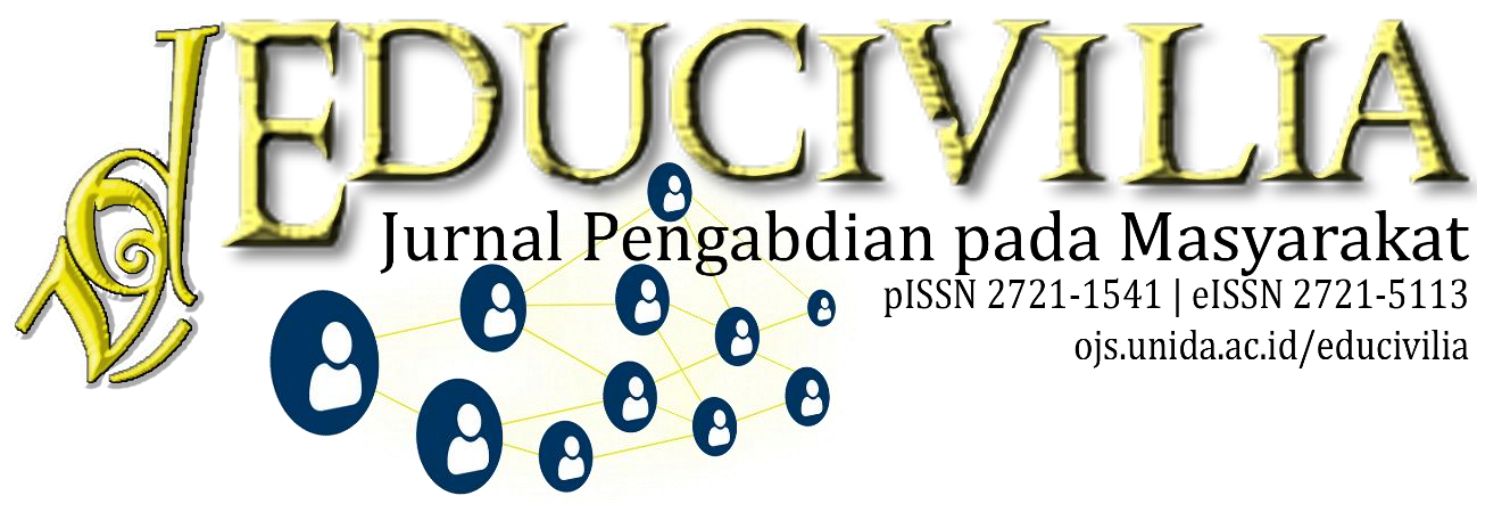

\title{
Pelatihan Manufaktur Komposit sebagai Produk Kerajinan Tangan pada Industri Rumahan
}

\author{
Anggara Trisna Nugraha1, Widya Emilia Primaningtyas ${ }^{3}$, Kharis Abdullah², Kiki \\ Dwi Wulandari², Benedicta Dian Alfanda ${ }^{3}$, Lely Pramesti ${ }^{3}$, Luqman Cahyono ${ }^{3}$, \\ Dwi Sasmita Aji Pambudi ${ }^{1}$, Sumardiono ${ }^{2}$ \\ 1Jurusan Teknik Kelistrikan Kapal, Politeknik Perkapalan Negeri Surabaya, Jalan Teknik Kimia \\ Kampus ITS, Keputih, Sukolilo, Surabaya, Jawa Timur, 60111, Indonesia \\ 2Jurusan Teknik Bangunan Kapal, Politeknik Perkapalan Negeri Surabaya, Jalan Teknik Kimia \\ Kampus ITS, Keputih, Sukolilo, Surabaya, Jawa Timur, 60111, Indonesia \\ ${ }^{3}$ Jurusan Teknik Permesinan Kapal, Politeknik Perkapalan Negeri Surabaya, Jalan Teknik Kimia \\ Kampus ITS, Keputih, Sukolilo, Surabaya, Jawa Timur, 60111, Indonesia
}

Kilas Artikel

Volume 1 Nomor 2

Juli 2020: 119-129

DOI: 10.30997/ejpm.v1i2.2943

Article History

Submission: 25-06-2020

Revised: 09-07-2020

Accepted: 14-07-2020

Published: 19-07-2020

Kata Kunci:

Manufaktur, kerajinan tangan, komposit, resin, pelatihan

\section{Keywords:}

composite, craft, manufacture, resin, workshop

Korespondensi:

Widya Emilia Primaningtyas (widyaemilia@ppns.ac.id)

\begin{abstract}
Abstrak
Berbagai kerajinan tangan dapat dikembangkan di masyarakat, salah satunya kerajinan tangan berbahan komposit yaitu menggunakan resin sebagai bahan utamanya. Metode pengecoran atau manufaktur bahan komposit ini memiliki variasi sesuai dengan resin yang digunakan atau peruntukkan komposit itu sendiri. Metode manufaktur ini dapat diaplikasikan oleh masyarakat dengan mudah, sehingga komposit yang dihasilkan dapat dimanfaatkan sebagai kerajinan tangan yang memiliki nilai tambah. Pelatihan metode manufaktur material komposit sebagai kerajinan tangan ini diberikan kepada Komunitas Riverside, Desa Suko, Kecamatan Sukodono, Kabupaten Sidoarjo. Pada prinsipnya pelatihan ini mengaplikasikan metode pengecoran sebagai dasar teknis aplikasi kerajinan tangan berbahan komposit. Pelatihan dilakukan dengan memberikan pengetahuan dasar tentang bahan resin dalam bentuk ceramah atau presentasi, kemudian dilakukan praktek metode manufaktur material komposit tersebut sehingga menghasilkan kerajinan tangan yang bernilai tinggi. Hasil kerajinan tangan berbahan komposit yang dihasilkan antara lain adalah gantungan kunci, bros, dan magnet hiasan kulkas.

\begin{tabular}{l} 
Composite Manufacturing Training as a Handicraft Product \\
in the Home Industry \\
Abstract \\
\hline Various handicrafts can be developed in the community, one of them \\
is handicraft made from composite which is using resin as its main \\
material. Method of casting or manufacturing composite materials \\
varies according to the resin used or the composition of the composite \\
\hline
\end{tabular}
\end{abstract}




itself. The manufacturing method can be applied by the community
easily, so that the resulting composite can be utilized as a handicraft
that has added value. Training on the method of manufacturing
composite materials as handicrafts was given to the Riverside Com-
munity, Suko Village, Sukodono District, Sidoarjo Regency. In prin-
ciple, this training applies casting material as a technical basis for
the application of composite handicrafts. The training is carried out
by providing basic knowledge about resin material knowledge in the
form of lectures or presentations, then practicing the methods of
manufacturing composite materials so as to produce high-value
handicrafts. Crafts made from composites produced include key
chains, brooches, and refrigerator decoration magnets.

\section{PENDAHULUAN}

Aset yang terbaik dalam diri manusia dan dapat menunjukkan kualitas pribadi seseorang adalah keterampilan hidup. Setiap orang memiliki bakat dan keterampilan yang bisa diasah, dilatih, dan dikembangkan sehingga menjadi nilai tambah bagi dirinya sendiri. Dengan keterampilan yang berkembang, maka pribadi tersebut akan menjalani kehidupan yang lebih berkualitas. Keterampilan dibagi menjadi empat, yaitu basic literacy skill, technical skill, interpersonal skill, dan problem solving. Untuk mengasah keterampilan merupakan salah satu media tersebut, diperlukan adanya pelatihan. Pelatihan memiliki tujuan agar seseorang dapat menguasai pengetahuan, keahlian, serta perilaku yang relevan dengan isi pelatihan dan dapat diterapkan dalam kehidupan sehari-hari.

Sebagai salah satu pengejawantahan tridharma perguruan tinggi, kegiatan pe- ngabdian masyarakat tenaga pendidik melakukan pendekatan ke masyarakat dalam upaya memberikan wawasan dan membantu menyelesaikan permasalahan sosial yang terjadi di masyarakat. Politeknik Perkapalan Negeri Surabaya sebagai salah satu perguruan tinggi vokasi di bidang maritim yang juga mempunyai tanggung jawab untuk berperan aktif memberikan wawasan atau menyelesaikan permasalahan sosial dengan cara yang sesuai bidang keahlian, yaitu di bidang maritim. Implementasi beberapa keilmuan yang digunakan di perguruan tinggi dapat digunakan untuk memberikan pelatihan pada suatu kelompok masyarakat demi menaikkan keterampilan dan nilai pribadi dari kelompok masyarakat tersebut.

Komposit merupakan salah satu ilmu material maju yang sedang berkembang pesat di berbagai industri, khususnya industri maritim (Davallo, et al,. 
Educivilia: Jurnal Pengabdian pada Masyarakat Volume 1 Nomor 2, Juli 2020

2010). Komposit sebagai material masa depan yang menjanjikan karakteristik material yang tangguh, tahan korosi, dan ringan sebagai pengganti logam maupun kayu. Komposit tersusun dari dua material atau lebih yang masing-masing elemennya mampu memperbaiki sifat mekanik dari elemen yang lain, dan menghasilkan material baru yang memiliki sifat unggul dari material penyusunnya (Sulistijono,2012). Kontribusi elemennya yang memungkinkan berasal dari sumber daya alam yang dapat diperbaharui menjadi salah satu alasan material komposit banyak digunakan. Dalam rangka memasyarakatkan wawasan tentang material maju khususnya tentang komposit, beriringan dengan usaha peningkatan wawasan dan keterampilan dari masyarakat awam maka pelatihan pembuatan komposit ini dilakukan. Pelatihan pembuatan komposit dikemas dalam cara sederhana, yang memungkinkan masyarakat awam untuk dapat mengerti titik berat dari konsep dasar pembuatan komposit. Pelatihan juga dirancang untuk membuat barang yang masuk dalam kategori komposit yang memanfaatkan bahan yang mudah dijumpai dalam rumah tangga, sekaligus dapat memberikan nilai tambah untuk bahan yang di-
p-ISSN 2721-1541 | e-ISSN 2721-5113

DOI: $10.30997 /$ ejpm.v1i2.2943

gunakan sebagai komposit. Pelatihan pembuatan kerajinan seperti gantungan kunci, bros, atau hiasan kulkas dari resin sebagai matriks dan daun daun kering, bunga, maupun kerang kerangan dilakukan sebagai salah satu wujud memasyarakatkan komposit. Pendampingan peningkatan keterampilan pembuatan kerajinan resin dimulai dari desain, pembuatan cetakan, proses pengecoran resin, pewarnaan dan finishing, sampai pemasaran dilaksanakan dalam program pelatihan yang dilakukan.

Wanita usia produktif yang berstatus ibu rumah tangga merupakan sasaran utama dilakukannya pelatihan pembuatan kerajinan resin ini. Terdapat 65 wanita usia produktif dari 50 Kepala Keluarga dibawah naungan 7 Rukun Tetangga di Perumahan Star Safira Regency yang tergabung dalam komunitas riverside. Wanita kategori usia produktif yaitu dengan rentang usia 20-55 tahun. Sebanyak 61\% wanita usia produktif di Perumahan Star Safira Regency merupakan ibu rumah tangga. Ibu-ibu dari komunitas riverside terbiasa melakukan kegiatan rutin untuk mengadakan pertemuan di tiap bulannya. Kegiatan pertemuan tersebut berisi kegiatan ramah tamah yang diisi dengan sharing 
pengalaman antar ibu-ibu anggota komunitas. Kegiatan pertemuan tersebut bertujuan untuk mempererat hubungan antar tetangga, agar lebih kompak dan harmonis.

Ibu-ibu anggota komunitas riverside dipilih menjadi peserta pelatihan pada kegiatan pengabdian masyarakat ini, karena masih tergolong usia produktif dan belum terdapat kegiatan kreatif dan inovatif yang dilakukan oleh warga Perumahan Star Safira Regency.

Dalam kesehariannya, beberapa ibu rumah tangga tersebut lebih banyak melakukan aktivitasnya di rumah untuk merawat anak dan mengerjakan pekerjaan rumah. Sehingga, tidak banyak aktivitas yang dilakukan di rumah. Selingan kegiatan positif dan bermanfaat, seperti pelatihan ini, perlu dilakukan oleh ibu rumah tangga, guna mengisi kegiatan keseharian di rumah dan membangun sinergi antar ibu-ibu anggota komunitas riverside. Pelatihan ini juga bertujuan untuk memberikan pembekalan dan semangat bagi ibu rumah tangga untuk tetap berkarya dan berpenghasilan dari rumah.

\section{METODE PELAKSANAAN}

Pelaksanaan praktek secara langsung dibutuhkan agar peserta lebih mu- dah dalam penyerapan dan pemahaman materi yang diberikan. Sehingga, metode workshop atau pelatihan dipilih sebagai metode yang digunakan dalam pelatihan ini. Di dalam metode tersebut, juga diberikan ceramah dan penugasan secara langsung.

Sebelum kegiatan dimulai, langkah awal yang perlu dilakukan adalah observasi. Tahap awal tersebut berguna untuk memahami dan mengkaji berbagai permasalahan dan potensi yang dimiliki oleh peserta. Observasi dilakukan selama dua bulan di Desa Suko, Kecamatan Sukodono, Kabupaten Sidoarjo. Target peserta dalam pelatihan ini adalah komunitas ibu rumah tangga produktif yang tergabung dalam Komunitas Riverside. Dengan terbentuknya komunitas tersebut di lapangan, maka akan lebih mudah untuk memetakan dan menentukan tema pelatihan yang cocok dengan kultur komunitas tersebut.

Setelah observasi, selanjutnya dilakukan sosialiasasi selama dua minggu sebelum kegiatan dimulai. Kegiatan sosialisasi meliputi detail model pelatihan, jumlah peserta, alat, dan bahan yang 
Educivilia: Jurnal Pengabdian pada Masyarakat Volume 1 Nomor 2, Juli 2020

diperlukan, serta penentuan lokasi pelatihan.

Kegiatan pengabdian kepada masyarakat ini dilaksanakan pada tanggal 23 November 2019 dengan judul Pelatihan Metode Manufaktur Komposit sebagai Kerajinan Tangan untuk Industri Rumahan. Kegiatan tersebut dilakukan selama 8 jam, di rumah salah satu peserta. Pelatihan dibagi menjadi dua sesi, yaitu pemaparan atau ceramah, dan praktek langsung pembuatan kerajinan tangan dengan bahan komposit. Kegiatan ini diharapkan dapat meningkatkan minat ibu-ibu untuk berwirausaha. Sehingga, ibu-ibu peserta pelatihan dapat menggunakan waktunya agar lebih produktif dan sekaligus membantu meningkatkan perekonomian keluarga.

Pada saat pelaksanaan praktek, pemateri melakukan demo tahapan-tahapan yang diperlukan dalam pembuatan kerajinan tangan berbahan komposit. Proses pembuatan dilakukan dengan menggunakan resin yang diberi pewarna dan ditambah pernak pernik. Kemudian, bahan resin tersebut dibentuk menjadi bros atau hiasan kulkas, sesuai dengan keinginan peserta. Setelah demo selesai, peserta dipersilahkan untuk
p-ISSN 2721-1541 | e-ISSN 2721-5113

DOI: $10.30997 /$ ejpm.v1i2.2943

mencoba membuat karya mereka sendiri. Pemateri yang terdiri dari 9 orang dosen, dan pembantu pemateri yang terdiri dari 3 orang mahasiswa, mengawasi langsung aktivitas peserta dalam pembuatan kerajinan tangan tersebut. Sebab, proses pembuatan kerajinan tersebut harus dilakukan dengan hati-hati.

Produk kerajinan yang sudah dihasilkan oleh peserta, kemudian tunggu hingga mengeras. Saat bahan resin sudah mengeras, maka produk kerajinan dapat dimasukkan ke dalam kemasan untuk dipasarkan. Produk kerajinan tersebut dapat dipasarkan baik secara langsung maupun online.

Setelah kegiatan selesai, evaluasi kegiatan dilakukan untuk mendapatkan informasi mengenai kendala yang dihadapi dan pencapaian selama kegiatan pengabdian kepada masyarakat ini berlangsung.

\section{HASIL \& PEMBAHASAN}

Kegiatan pengabdian masyarakat yang diselenggarakan di Desa Sukodono, dengan keseluruhan peserta sejumlah 37 orang yang tergabung dalam komunitas riverside, yang hampir seluruh peserta berstatus ibu rumah tangga berjalan sesuai dengan jadwal dan ren- 
cana. Respon antusias peserta tentang teknologi manufaktur sederhana dengan bahan komposit dibuktikan dengan keaktifan peserta dalam proses pemaparan materi dan praktek. Stimulus yang diberikan berupa pengetahuan proses manufaktur dan komposit yang ada meningkatkan rasa ketertarikan (interest) terhadap pembuatan produk. Seperti terlihat pada Gambar 1. peserta tertarik dan memberikan respon yang baik pada saat proses pemaparan materi tentang manufaktur komposit. Sesuai dengan yang dijelaskan oleh Notoatmodjo, 2003 bahwasanya proses terjadinya pengetahuan diawali dengan stimulus yang diberikan sehingga akan timbul rasa tertarik. Lebih lanjut, dengan ketertarikan yang ada akan meningkat menjadi mencoba dan mengadopsi cara kerja pembuatan produk. Pada kegiatan pengabdian yang dilaksanakan, peserta aktif dalam pembuatan produk, sehingga bisa mengetahui dan mempraktekkan langkah-langkah yang telah diterangkan hingga berhasil membuat produk yang ada.

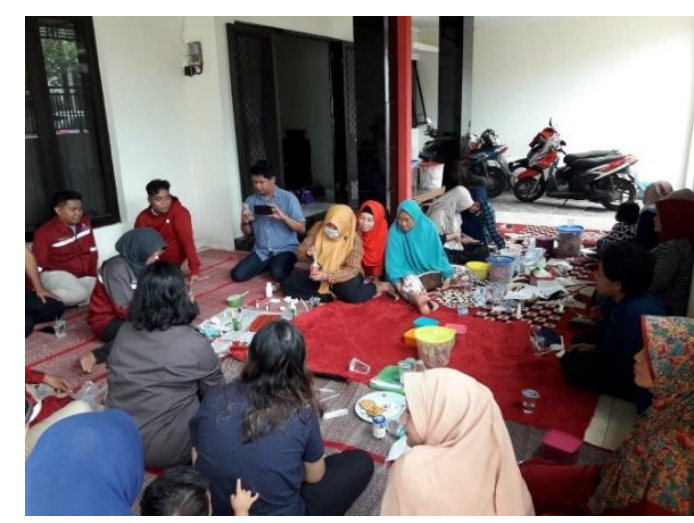

Gambar 1. Proses pemaparan materi

Pada pelaksanaan pengabdian masyarakat yang dilakukan dengan aktif dan interaktif, timbul motivasi dalam individu peserta untuk memanfaatkan potensi yang ada. Dengan pemaparan yang mudah dan sederhana, tentang SWOT (strength, weaknesses opportunities, threats) peluang bisnis kerajinan tangan dari komposit yang ada, menjadikan peserta yang merupakan ibu rumah tangga semakin tertarik dan memahami peluang wirausaha yang bisa dilakukan dari rumah. Terlihat pada Gambar 2. peserta aktif pada saat proses demo atau praktek yang dilakukan oleh pemateri, sekaligus dengan tanya jawab tentang proses manufaktur komposit dan peluang-peluang wirausaha yang dapat diciptakan. Dengan pengetahuan pembuatan manufaktur komposit yang dikombinasikan dengan analisis SWOT yang dibawakan dengan sederhana, menghasilkan peserta menjadi lebih 
memahami keahlian, strategi berkarya dan bekerja dari rumah. Hasil pemahaman peserta tentang strength, weaknesses opportunities, threats yang ada sehingga dapat menyusun strategi berkarya dari rumah, sesuai dengan penjelasan Sammut dan Galea, 2015. Tujuan dari analisis SWOT adalah menyusun strategi dengan menggunakan pengetahuan yang dimiliki tentang lingkungan internal dan eksternal.

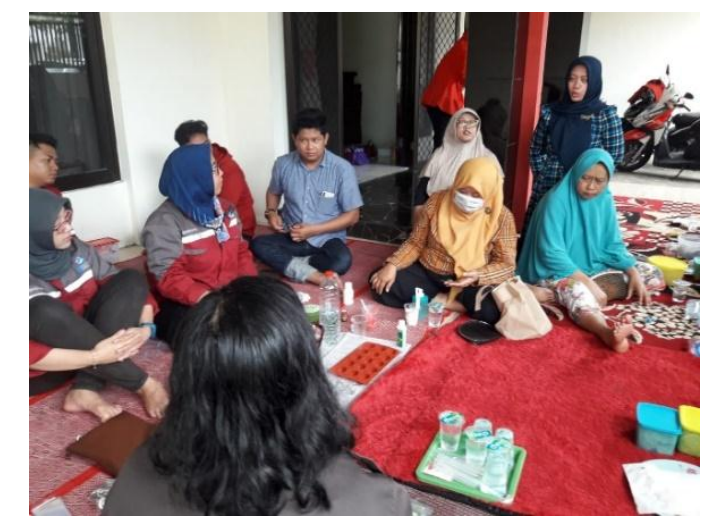

Gambar 2. Pemateri melakukan demo sekaligus tanya jawab dengan peserta

Proses pelaksanaan pembuatan kerajinan tangan berupa pembuatan gantungan kunci, bros dan hiasan kulkas dilakukan dengan baik oleh peserta. Peserta membuat kerajinan sesuai dengan instruksi dan langkah-langkah yang ada, mulai dari proses desain, pencetakan hingga finishing dengan dibungkus menggunakan plastik sehingga meningkatkan nilai dari produk kerajinan tangan yang dibuat. Pada Error! Reference source not found..
Proses pelaksanaan pembuatan kerajinan tangan berupa pembuatan gantungan kunci, bros dan hiasan kulkas dilakukan dengan baik oleh peserta. Peserta dapat melakukan pembuatan sesuai dengan instruksi dan langkahlangkah yang ada, mulai dari proses desain, pencetakan hingga finishing dengan dibungkus menggunakan plastik sehingga bisa meningkatkan nilai dari produk kerajinan tangan yang dibuat. Pada Error! Reference source not found.. dapat dilihat proses pencetakan yang dilakukan oleh peser-ta. Dalam proses praktek yang dilaku-kan oleh peserta, disertai dengan proses tanya jawab seperti jenis resin, kompo-sisi bahan, tempat pembelian bahan, harga material dan lain-lain.

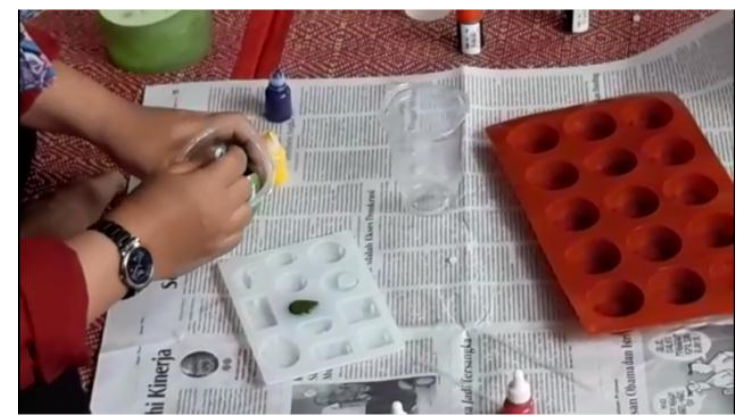

Gambar 3 Pencetakan gantungan kunci

Salah satu yang menjadi topik pembahasan utamanya yaitu mengenal jenis resin. Resin yang digunakan dalam pelatihan ini adalah polimer berbentuk cair, bening, kental, dan berbau menyengat. Terdapat berbagai jenis resin yang dapat dipergunakan sebagai bahan kerajinan (Muis, 2018). Resin bening banyak digunakan untuk menonjolkan kebeningannya, dapat juga digunakan 
Pelatihan Metode Manufaktur Komposit sebagai Produk Kerajinan Tangan...

sebagai media pengawetan, sedangkan untuk resin keruh lebih banyak digunakan untuk pembuatan souvenir yang tidak tembus pandang. Penggunaan resin untuk aksesoris sangat digemari selain karena mudah dibeli di toko bahan kimia dan harganya murah. (Ni Made Ary Widiastini, Nyoman Dini Andiani, 2017). \& Community, 2011).

Hal ini penting untuk diketahui karena jenis bahan menentukan hasil akhir dari produk yang dibuat. Semakin dalam pembahasan yang dipaparkan, ibu-ibu peserta pelatihan semakin antusias.

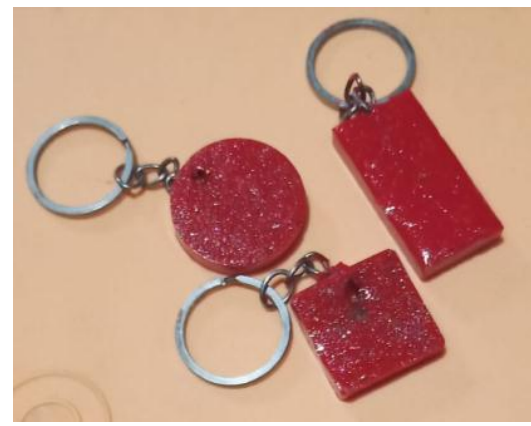

Gambar 4. Gantungan Kunci Resin hasil pelatihan

Gambar 3 dan 4 memperlihatkan foto-foto hasil dari proses pelaksanaan dan hasil produk yang dibuat pada kegiatan pengabdian masyarakat yang dilakukan ibu-ibu Komunitas Riverside, Desa Suko, Kecamatan Sukodono.

Sasaran dalam pengabdian masyarakat yang dilakukan oleh PPNS, adalah ibu rumah tangga di Perumahan Star Safira di Desa Sukodono. Semua peserta mengikuti dan melaksanakan pelatihan sesuai jadwal dan sampai selesai. Berdasarkan hasil pengamatan dan respon yang diberikan oleh peserta, terlihat perbedaan sebelum dan setelah dilaksanakan pengabdian masyarakat, terdapat perubahan dan penambahan dalam pengetahuan serta keterampilan dalam membuat kerajinan tangan berbahan komposit. Selain itu, para peserta mengetahui tentang potensi, peluang yang ada, serta timbul motivasi untuk tetap berkarya dalam rumah tanpa meninggalkan kewajiban sebagai ibu rumah tangga.

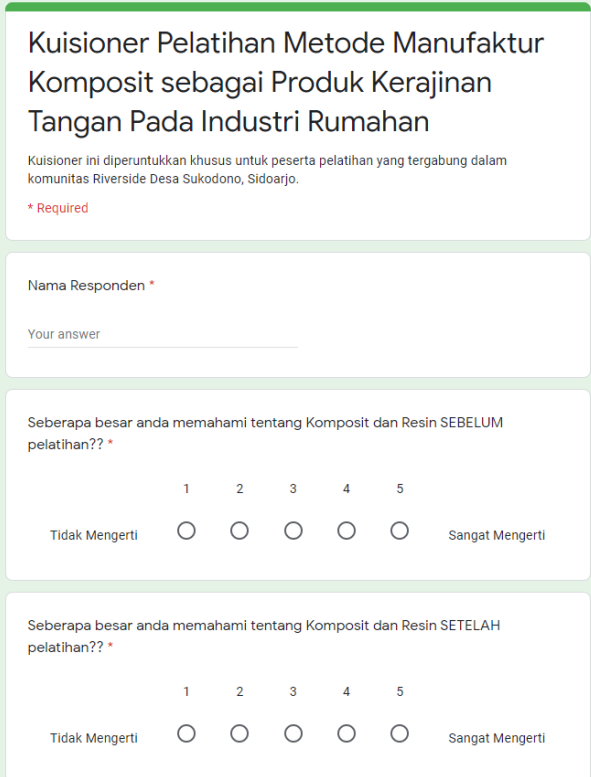

Gambar 5. Kuisioner pelatihan yang diberikan melalui Google Form 
Untuk mengetahui tingkat keberhasilan kegiatan pengabdian kepada masyarakat ini juga dilakukan evaluasi kepada peserta dalam bentuk kuisioner yang dapat diakses melalui google form dan diisi secara online seperti tampilan pada Gambar 5. dan bisa diakses pada tautan shorturl.at/iCKNX Materi pelatihan juga dibagikan secara daring dapat diakses pada tautan sebagai berikut shorturl.at/wAHMU

Dari hasil evaluasi menggunakan kuisioner tersebut Komunitas Riverside rata-rata sangat antusias terhadap pelatihan yang diberikan. Pemahaman terhadap materi pelatihan yang diberikan adalah sangat baik dan $86 \%$ dari total seluruh peserta memahami materi pelatihan. Terjadi peningkatan signifikan sebesar $68 \%$ dari jumlah peserta yang paham tentang tema pelatihan sebelum dan sesudah penyampaian pelatihan seperti yang tampak pada Gambar 6. hal ini salah satu data yang membuktikan keberhasilan dari pelatihan.

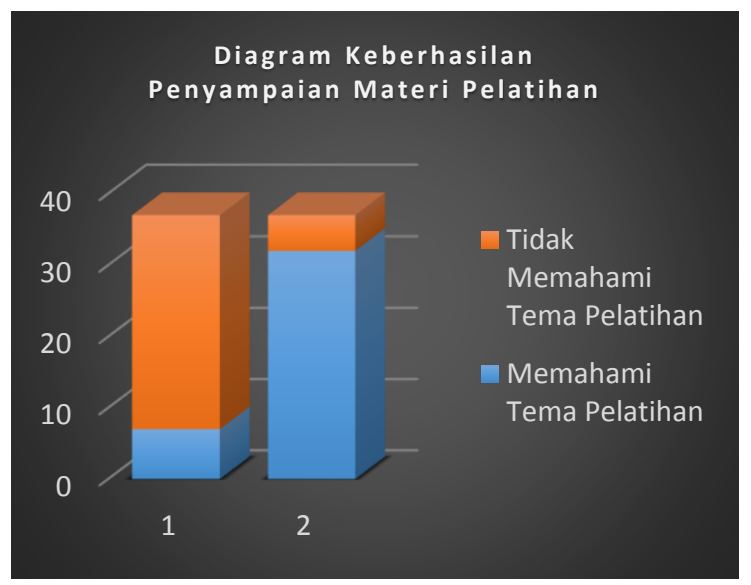

Gambar 6. Diagram keberhasilan penyampaian materi pelatihan.

Pelatihan yang diadakan juga mendorong member komunitas riverside untuk menjadi entrepreneur dengan membuka toko online di berbagai platform belanja online, dengan menjual barang hasil kerajinan tangan komposit resin seperti yang ditunjukkan pada Gambar 7.

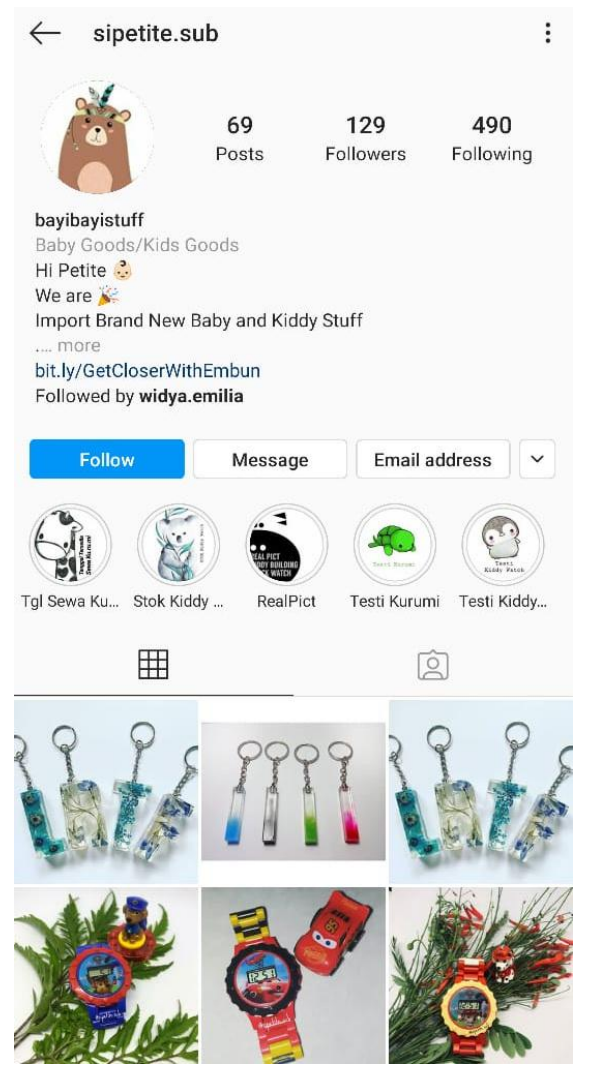

(a) 


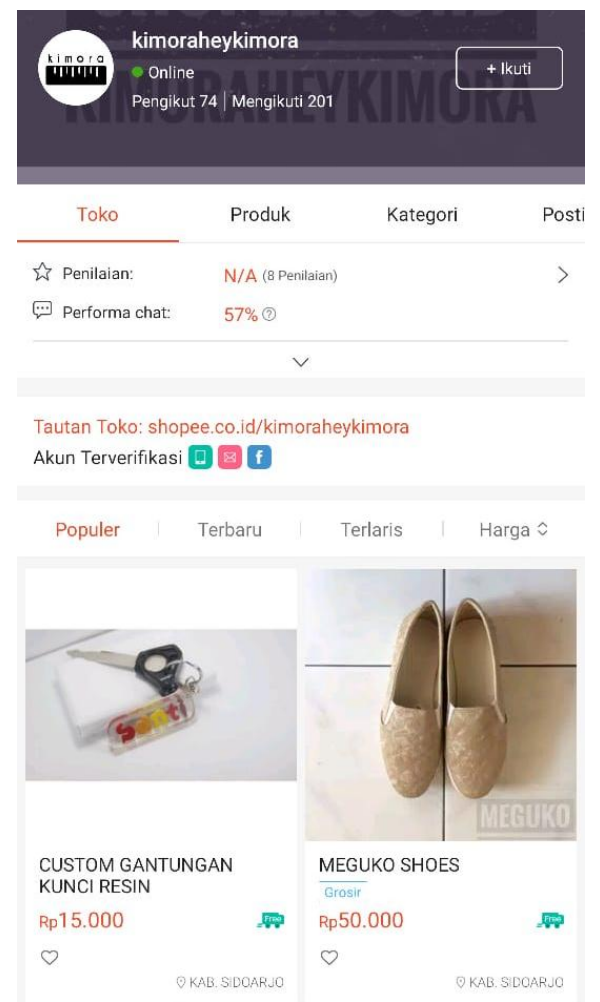

(b)

Gambar 7. Toko online peserta pelatihan pembuatan kerajinan tangan komposit.

Dengan adanya kegiatan pengabdian kepada masyarakat oleh PPNS diharapkan dapat menambah dan memperluas wawasan pengetahuan serta keterampilan kepada ibu-ibu Komunitas Riverside, Desa Suko, Kecamatan Sukodono tentang teknologi tepat guna.

Sebagai langkah awal bagi Komunitas Riverside, Desa Suko, Kecamatan Sukodono dapat mengembangkan industri rumah tangga dalam skala komersial.

\section{SIMPULAN}

Kegiatan pengabdian kepada masyarakat yang telah dilakukan ini ber- jalan dengan baik. Beberapa manfaat secara langsung dapat dirasakan oleh Komunitas Riverside, Desa Suko, Kecamatan Sukodono, Kabupaten Sidoarjo, yang terdiri dari ibu-ibu produktif ini, yaitu menambah keterampilan dalam pembuatan kerajinan tangan komposit berbahan resin yang sebelumnya belum pernah dilakukan. Selain itu, pelatihan ini mampu meningkatkan kesadaran Komunitas Riverside dalam memulai berwirausaha. Kemudahan dalam pembuatan kerajinan ini menjadi pemicu Komunitas Riverside untuk menginisiasi penjualan produk kerajinan tangan tersebut, sehingga tim pengabdian kepada masyarakat ini mendapatkan usulan untuk memberikan pelatihan lanjutan dengan tema pemasaran produk secara online. Selain itu, komunitas ini juga mengharapkan adanya pelatihan-pelatihan dengan tema lain secara reguler dengan jumlah peserta dan waktu pelatihan yang lebih banyak lagi, sehingga komunikasi dengan masyarakat dapat terjalin dengan baik dan bermanfaat.

\section{DAFTAR PUSTAKA}

Davallo,M, Pasdar,H. dan Mohseni,M. 2010. Mechanical Properties of Unsaturated Polyester Resin. International Journal of ChemTech Research. 
Muis, A. (2018). Pelatihan pemanfaatan limbah bengkel menjadi merchandise dan peraga pengenalan part motor berbahan resin. In Unesa (pp. 1-6). Surabaya.

Ni Made Ary Widiastini, Nyoman Dini Andiani, N. L. P. A. K. (2017). Pelatihan Pembuatan Cinderamata sebagai Produk Wisata bagi Masyarakat Pedagang Acung di Desa Batur Jawa Tengah. Jurnal IKB, 21(Xi), 31-41.

Notoatmodjo, Soekidjo, 2003, Pengembangan Sumber Daya Manusia, Jakarta: PT. Rineka Cipta.

Sulistijono. 2012. Mekanika Material Komposit. Surabaya : Institut Teknologi Sepuluh Nopember.

Tanya Sammut-Bonnici and David Galea. 2015. SWOT Analysis. Wiley Encyclopedia of Management 